\title{
Synthesis, Characterization and Anticonvulsant Activity of Some Novel 4, 5-Disubstituted-1, 2, 4-Triazole Derivatives
}

\author{
Yasmin Khatoon $^{\mathrm{a}^{*}}$, Mohammad Shaquiquzzaman ${ }^{\mathrm{b}}$, Vijender Singh $^{\mathrm{a}}$, Mohammad Sarafroz ${ }^{\mathrm{c}}$ \\ ${ }^{a}$ School of Pharmacy, Sharda University, Knowledge Park III, Greater Noida, Uttar Pradesh 201306, India. \\ ${ }^{b}$ Department of Pharmaceutical Chemistry, Faculty of Pharmacy, Jamia Hamdard University, New Delhi-110062, India. \\ ${ }^{c}$ Department of Pharmaceutical Chemistry, College of Clinical Pharmacy, University of Dammam, Dammam- 31441, Kingdom of Saudi Arabia.
}

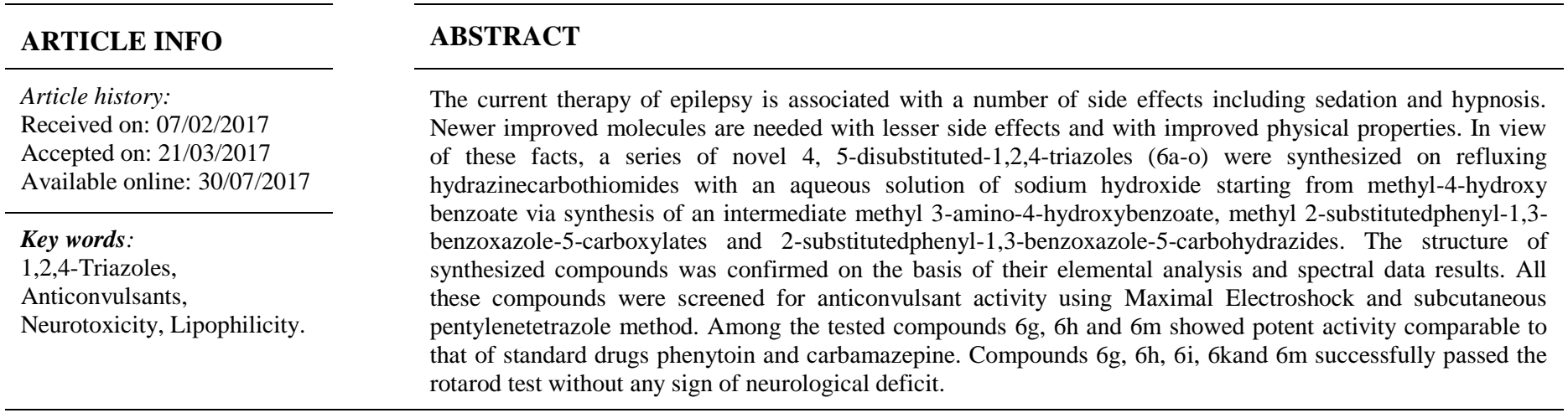

\section{INTRODUCTION}

Epilepsy is not a disease, but a syndrome of different cerebral disorders of central nervous system, and it is characterized by paroxysmal, excessive and hypersynchronous discharges of large numbers of neurons (McNamara, 1999; Kaushik et al., 2010). Being one of the world's oldest recognized disorders, it is surrounded by fear, discrimination, social and frightening manifestation (Daras et al., 2007). In fact, epilepsy is the second most prevalent neurological disorder after stroke in the industrial world (Korczyn et al., 2015). It is one of the most common neurological disorders, affecting $0.5-1 \%$ of the population worldwide (45-100 million people)

\section{* Corresponding Author}

School of Pharmacy, Sharda University,

Knowledge Park III,Greater Noida, Uttar Pradesh 201306, India..

Phone No.: +91-9453876953; E-mail: yassu.ayaan @ gmail.com
(Njamnshi et al., 2010; Blum, 1998; Bell and Sander, 2002; Husain et al., 2011; Wlaz and Loscher, 1998; Scheurer and Pedley, 1990). Every year approximately 250000 new cases are added to this figure (Siddiqui et al., 2007). Many drugs have been marketed recently for the treatment of epilepsy (Sabers and Gram, 2000; Brittonm and So, 1995; Loscher, 1998).

Several newer antiepileptic drugs (such as pregabalin, stiripentol, zonisamide, tiagabine, lamotrigine, levetiracetam, topiramate) are greatly compromised by severe side effects such as vertigo, ataxia, headache, hirsutism, hepatotoxicity, gastrointestinal and cardiovascular. Moreover about 30\% of patients have uncontrolled seizures (Kwan and Brodie, 2000; Spear, 2001). The insufficient information on the cellular mechanism of epilepsy in humans and the complex mechanism of action of most of the antiepileptic drugs makes it difficult to use rational methodologies in the field of drug discovery. There is a substantial need for the development of new, more effective and less toxic antiepileptic drugs (Smith et al., 2007). 
The literature survey revealed that the anticonvulsant activity is mainly attributed due to the presence of aryl binding site (A) with aryl/alkyl hydrophobic group, hydrogen bonding domain (HBD) and electron donor group (D) (Dimmock et al., 2000a,b). Pandeya et al., (2002) while investigating the semicarbazone series, proposed a new pharmacophore model with four binding sites essential for anticonvulsant activity (Figure 1). These sites are:

- A hydrophobic aryl ring,

- A hydrogen-bonding domain,

- An electron donor acceptor system,

- Another hydrophobic aryl ring responsible for metabolism

These groups were found in the structures of wellestablished antiepileptics such as phenytoin, albutoin, rufinamide, phenobarbital, diazepam, carbamazepineand lamotrigine(Figure 2) (Unverferth et al., 1998).

Therefore, continued search for novel antiepileptic drugswith less toxicity and more selectivity continues to be an area of investigation in the field of medicinal chemistry. Many studies revealed that the triazole ring is an important lead moiety in the field of agriculture, microbiology and medicine which exhibits a broad spectrum of biological activities such as anticancer (Li et al., 2009), anti-inflammatory (Salgın-Goksen et al., 2007; Kumar et al., 2008), analgesic (Salgin-Goksen et al., 2007), antimicrobial (Gumrukcuoglu et al., 2007), antitubercular (Klimesova et al., 2004), bactericidal (Guzeldemirci et al., 2010), fungicidal (Siddiqui et al., 2005), insecticidal (Chai et al., 2003), herbicidal (Ma et al., 2006) and CNS stimulant (Nagai et al., 1998) activities. Literature survey reveals that 4, 5-disubstituted2,4 dihydro-3H-1,2,4-triazole derivatives have not been paid much attention for their anticonvulsant properties.

These exciting manifold activities of triazole derivatives stimulated us to synthesize a series of4, 5-disubstituted-2,4 dihydro-3H-1,2,4-triazole derivatives for their potential antiepileptic properties by using pharmacophoric features with aromatic hydrophobic aryl (A), $\mathrm{NH}-\mathrm{C}=\mathrm{S}$ as hydrogen bonding domains (HBD), nitrogen atom as electron donor (D) and phenyl as distal aryl ring (C) (Figure 2).

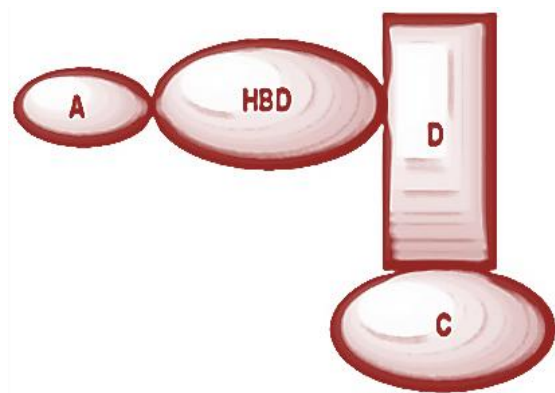

Fig. 1: Suggested pharmacophore model for anticonvulsant activity. A: hydrophobic domain, HBD: hydrogen bonding domain, C: distal hydrophobic domain, D: electron donor moiety.

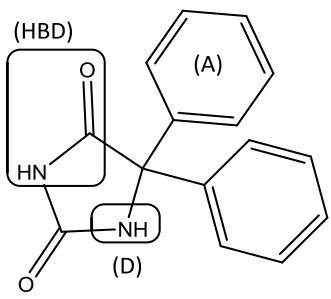

Phenytoin

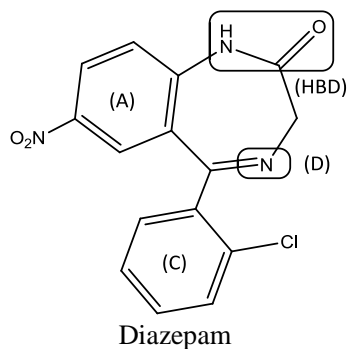

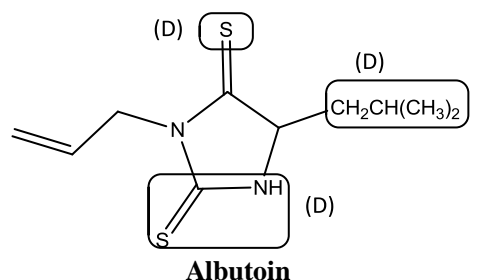

Albutoin

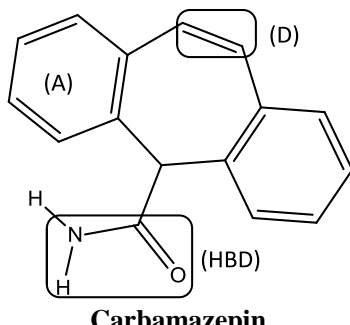

Carbamazepin

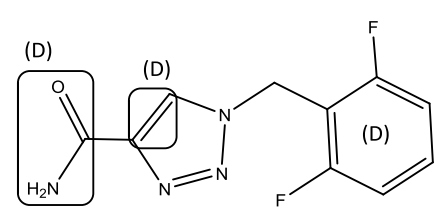

Rufinamide

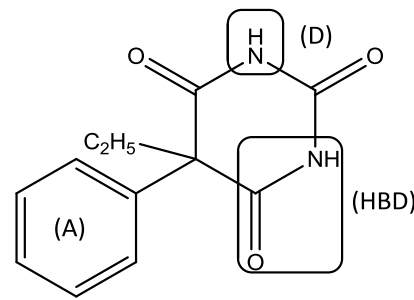

Phenobarbital

Fig. 2: Structure of proposed general pharmacophore model of the synthesized compound and reported chemical drugs. 


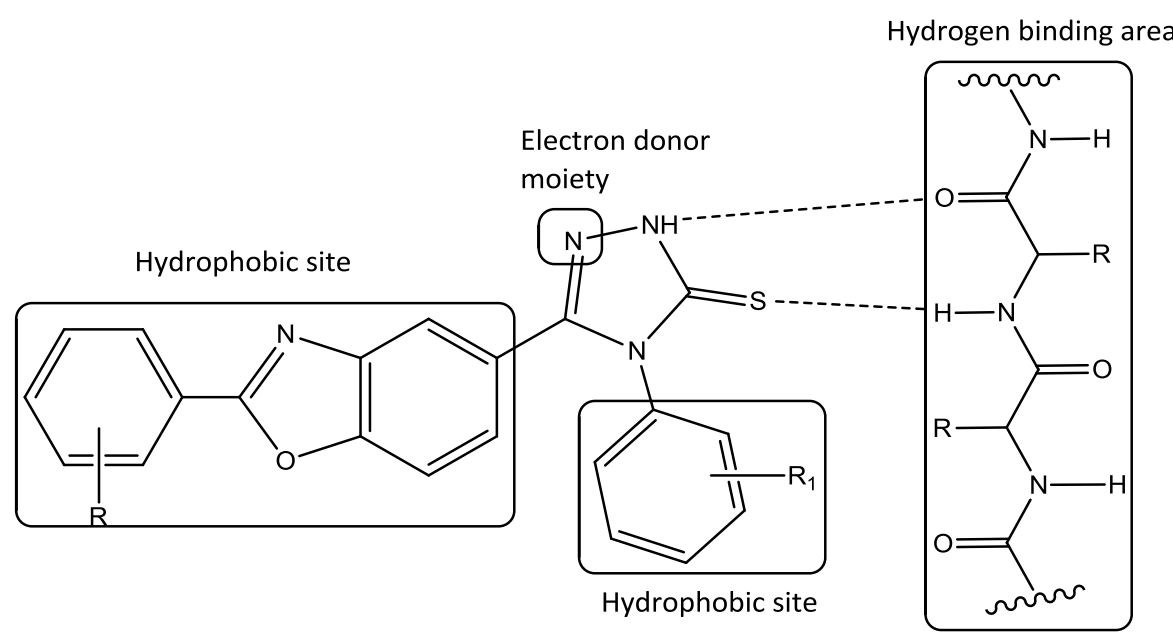

Fig. 3: Proposed binding interactions of the title compounds using putative binding site theory (Dimmock et al., 2000a, b; Gibson et al., 2009; Pandeya et al., 2002).

Table 1: Physicochemical parameters of synthesized compounds (6a-o).

\begin{tabular}{|c|c|c|c|c|c|c|c|}
\hline CodeNo. & $\mathbf{R}$ & $\mathbf{R}^{1}$ & Mol. formula $^{a}$ & $\mathbf{M . P}^{\mathrm{b}}\left({ }^{\circ} \mathbf{C}\right)$ & $\%$ yield & $\log P^{c}$ & $\mathbf{R}_{\mathrm{f}}^{\mathrm{d}}$ Value \\
\hline $6 a$ & $\mathrm{C}_{6} \mathrm{H}_{5}$ & $2-\mathrm{CH}_{3} \mathrm{C}_{6} \mathrm{H}_{4}$ & $\mathrm{C}_{22} \mathrm{H}_{16} \mathrm{~N}_{4} \mathrm{OS}$ & $100-102$ & 40 & 0.71 & 0.50 \\
\hline $6 b$ & $\mathrm{C}_{6} \mathrm{H}_{5}$ & $3-\mathrm{CH}_{3} \mathrm{C}_{6} \mathrm{H}_{4}$ & $\mathrm{C}_{22} \mathrm{H}_{16} \mathrm{~N}_{4} \mathrm{OS}$ & $115-117$ & 55 & 0.80 & 0.61 \\
\hline $6 c$ & $\mathrm{C}_{6} \mathrm{H}_{5}$ & 4- $\mathrm{CH}_{3} \mathrm{C}_{6} \mathrm{H}_{4}$ & $\mathrm{C}_{22} \mathrm{H}_{16} \mathrm{~N}_{4} \mathrm{OS}$ & 95-97 & 45 & 0.81 & 0.67 \\
\hline $6 \mathrm{~d}$ & $3-\mathrm{ClC}_{6} \mathrm{H}_{4}$ & $2-\mathrm{CH}_{3} \mathrm{C}_{6} \mathrm{H}_{4}$ & $\mathrm{C}_{22} \mathrm{H}_{15} \mathrm{ClN}_{4} \mathrm{OS}$ & $120-122$ & 65 & 1.95 & 0.79 \\
\hline $6 \mathrm{e}$ & $3-\mathrm{ClC}_{6} \mathrm{H}_{4}$ & $3-\mathrm{CH}_{3} \mathrm{C}_{6} \mathrm{H}_{4}$ & $\mathrm{C}_{22} \mathrm{H}_{15} \mathrm{ClN}_{4} \mathrm{OS}$ & $110-112$ & 59 & 1.04 & 0.70 \\
\hline $6 \mathrm{f}$ & $3-\mathrm{ClC}_{6} \mathrm{H}_{4}$ & 4- $\mathrm{CH}_{3} \mathrm{C}_{6} \mathrm{H}_{4}$ & $\mathrm{C}_{22} \mathrm{H}_{15} \mathrm{ClN}_{4} \mathrm{OS}$ & $125-127$ & 61 & 1.89 & 0.71 \\
\hline $6 \mathrm{~g}$ & 4- $\mathrm{ClC}_{6} \mathrm{H}_{4}$ & $2-\mathrm{CH}_{3} \mathrm{C}_{6} \mathrm{H}_{4}$ & $\mathrm{C}_{22} \mathrm{H}_{15} \mathrm{ClN}_{4} \mathrm{OS}$ & $125-127$ & 67 & 1.71 & 0.69 \\
\hline $6 \mathrm{~h}$ & $4-\mathrm{ClC}_{6} \mathrm{H}_{4}$ & $3-\mathrm{CH}_{3} \mathrm{C}_{6} \mathrm{H}_{4}$ & $\mathrm{C}_{22} \mathrm{H}_{15} \mathrm{ClN}_{4} \mathrm{OS}$ & $140-142$ & 79 & 1.86 & 0.56 \\
\hline $6 \mathrm{i}$ & 4- $\mathrm{ClC}_{6} \mathrm{H}_{4}$ & 4- $\mathrm{CH}_{3} \mathrm{C}_{6} \mathrm{H}_{4}$ & $\mathrm{C}_{22} \mathrm{H}_{15} \mathrm{ClN}_{4} \mathrm{OS}$ & $135-137$ & 39 & 1.79 & 0.88 \\
\hline $6 j$ & $3-\mathrm{BrC}_{6} \mathrm{H}_{4}$ & $2-\mathrm{CH}_{3} \mathrm{C}_{6} \mathrm{H}_{4}$ & $\mathrm{C}_{22} \mathrm{H}_{15} \mathrm{BrN}_{4} \mathrm{OS}$ & $145-147$ & 48 & 1.98 & 0.71 \\
\hline $6 \mathrm{k}$ & $3-\mathrm{BrC}_{6} \mathrm{H}_{4}$ & $3-\mathrm{CH}_{3} \mathrm{C}_{6} \mathrm{H}_{4}$ & $\mathrm{C}_{22} \mathrm{H}_{15} \mathrm{BrN}_{4} \mathrm{OS}$ & $130-132$ & 67 & 1.83 & 0.67 \\
\hline 61 & $3-\mathrm{BrC}_{6} \mathrm{H}_{4}$ & 4- $\mathrm{CH}_{3} \mathrm{C}_{6} \mathrm{H}_{4}$ & $\mathrm{C}_{22} \mathrm{H}_{15} \mathrm{BrN}_{4} \mathrm{OS}$ & $125-127$ & 70 & 0.99 & 0.77 \\
\hline $6 \mathrm{~m}$ & $4-\mathrm{BrC}_{6} \mathrm{H}_{4}$ & $2-\mathrm{CH}_{3} \mathrm{C}_{6} \mathrm{H}_{4}$ & $\mathrm{C}_{22} \mathrm{H}_{15} \mathrm{BrN}_{4} \mathrm{OS}$ & $140-142$ & 71 & 1.96 & 0.46 \\
\hline $6 n$ & 4- $\mathrm{BrC}_{6} \mathrm{H}_{4}$ & $3-\mathrm{CH}_{3} \mathrm{C}_{6} \mathrm{H}_{4}$ & $\mathrm{C}_{22} \mathrm{H}_{15} \mathrm{BrN}_{4} \mathrm{OS}$ & $145-147$ & 56 & 1.87 & 0.61 \\
\hline 60 & $4-\mathrm{BrC}_{6} \mathrm{H}_{4}$ & 4- $\mathrm{CH}_{3} \mathrm{C}_{6} \mathrm{H}_{4}$ & $\mathrm{C}_{22} \mathrm{H}_{15} \mathrm{BrN}_{4} \mathrm{OS}$ & $150-152$ & 50 & 1.80 & 0.71 \\
\hline
\end{tabular}

${ }^{a}$ Solvent of crystallization - ethanol.

${ }^{\mathrm{b}}$ Melting point of the compounds at their decomposition.

${ }^{\circ} \mathrm{Log} \mathrm{P}$ was calculated using absorbance data, chloroform / phosphate buffer at $28{ }^{\circ} \mathrm{C}$.

${ }^{\mathrm{d}}$ Solvent system — benzene : acetone $(8: 2,7: 3$ and $6: 4)$, toluene : ethylacetate : formic acid $(5: 4: 1)$.

Table 2: Anticonvulsant and motor impairment screening of synthesized compounds (6a-o).

\begin{tabular}{|c|c|c|c|c|c|c|}
\hline \multirow[t]{3}{*}{ Code No. } & \multicolumn{4}{|c|}{ Intraperitoneal injection in mice ${ }^{\mathrm{a}}$} & \multicolumn{2}{|c|}{ Neurotoxicity screen ${ }^{a}$} \\
\hline & \multicolumn{2}{|c|}{ MES screen } & \multicolumn{2}{|c|}{ scPTZ screen } & & \\
\hline & $0.5 \mathrm{~h}$ & $4 \mathrm{~h}$ & $0.5 \mathrm{~h}$ & $4 \mathrm{~h}$ & $0.5 \mathrm{~h}$ & $4 \mathrm{~h}$ \\
\hline 6a & - & - & - & - & $x$ & $x$ \\
\hline $6 \mathbf{b}$ & 300 & - & 300 & - & 300 & - \\
\hline 6c & - & - & - & - & $x$ & $x$ \\
\hline 6d & 100 & 300 & 300 & - & - & 300 \\
\hline $6 e$ & 300 & - & - & - & 300 & - \\
\hline $6 f$ & 100 & 300 & 300 & - & 300 & - \\
\hline $6 \mathrm{~g}$ & 30 & 300 & 300 & - & - & - \\
\hline $6 \mathrm{~h}$ & 30 & 300 & 300 & 300 & - & - \\
\hline $6 \mathbf{i}$ & 100 & 300 & - & 300 & - & - \\
\hline $6 \mathbf{j}$ & 100 & 300 & - & 300 & 300 & 300 \\
\hline $6 \mathbf{k}$ & 100 & 300 & 300 & - & - & - \\
\hline 61 & 300 & - & 300 & - & - & 300 \\
\hline $6 m$ & 30 & 300 & - & 300 & - & - \\
\hline $6 n$ & 100 & 300 & - & 300 & - & 300 \\
\hline 60 & 100 & 300 & 300 & 300 & 300 & 300 \\
\hline Phenytoin ${ }^{\mathrm{b}}$ & 30 & 30 & - & - & 100 & 100 \\
\hline Carbamazepine $^{\mathrm{b}}$ & 30 & 100 & 100 & 300 & 300 & 300 \\
\hline
\end{tabular}

${ }^{a}$ Doses of 30,100 and $300 \mathrm{mg} / \mathrm{kg}$ were administered to mice through intraperitoneal route. The figures in the table indicate the minimum dose where by bioactivity was demonstrated in half or more of the mice. The animals were examined 0.5 and 4 hrsafter the drug administration. The dash (-) indicates an absence of activity at maximum dose administered $(300 \mathrm{mgkg})$ and cross $(\times)$ denotes not tested. Propylene glycol $(0.1 \mathrm{ml}$, i.p. $)$ was used as control solvent.

${ }^{b}$ Data of Phenytoin and Carbamazepine, used as standard drugs, were obtained referring, Dimmock et al 1995 and White et al 1995. 


\section{MATERIALS AND METHODS}

All the chemicals and solvents used were mostly of laboratory grade obtained from Merck, $\mathrm{CDH}$ and SD Fine Chemicals Limited. The reactions were monitored by thin layer chromatography (TLC) using benzene: acetone (8:2, 7:3 and 6:4) and toluene: ethyl acetate: formic acid (5:4:1) as solvent systems. Iodine chamberand UV lamp were used for visualization of TLC spots. The ${ }^{1} \mathrm{H}-\mathrm{NMR}$ spectra were recorded on DRX- 300 NMRand BRUKER 400 Ultra Shield $^{\mathrm{TM}}$ spectrometer (chemical shifts in $\delta$, ppm) in DMSO- $d 6$ using TMS as internal reference, mass spectra were recorded on a UPLC-MS/MS (WATERS, Mass Lynx version 4.1) spectrometer and IR spectra were recorded in $\mathrm{KBr}$ pellets on (BIO-RADS) FTS-135 spectrometer. Microanalyses of the compounds were done on Perkin-Elmer model 240 analyzer and the values were found within $\pm 0.4 \%$ of the theoretical values. The melting points were determined in open glass capillary using Kjeldahl flask containing liquid paraffin and are uncorrected. The physicochemical parameters and anticonvulsant screening of the synthesized compounds are presented in Table 1 and 2 respectively.

\section{EXPERIMENTAL PROTOCOL}

Method of synthesis

Synthesis of methyl 4-hydroxy-3-nitrobenzoate (1)

To a solution of aluminium nitrate $(20 \mathrm{gm})$ in acetic acid: acetic anhydride $(1: 1)$ mixture $(80 \mathrm{~mL})$ was added an appropriate methyl-4-hydroxy benzoate $(20 \mathrm{gm})$ in small portions, while cooling and shaking occasionally. The reaction mixture was left at room temperature for $2 \mathrm{hrs}$ while shaking the contents intermittently to complete the nitration. The resulting brown solution was diluted with ice cold water $(250 \mathrm{~mL})$ and acidified with concentrated nitric acid $(20 \mathrm{~mL})$ to get a bulky yellow precipitate. It was filtered and washed with small quantity of methanol and purified by recrystallization from alcohol to get a yellow crystalline compound (1)(Gopalakrishna et al., 2005).

\section{Synthesis of Methyl-3-amino-4-hydroxybenzoate (2)}

Methyl 4-hydroxy-3-nitrobenzoate(15gm) was dissolved in boiling ethanol $(200 \mathrm{~mL})$ and sodium dithionite was added to this boiling alcohol until it becomes almost colorless. Then the solvent was reduced to one third of its volume by distillation and the residual liquid was triturated with crushed ice. Usual work up of the reaction mixture gave pure compound (2) (Gopalakrishna et al., 2005).

\section{General procedure for synthesis of methyl 2-substitutedphenyl- 1,3-benzoxazole-5-carboxylates (3a-e)}

A mixture of Methyl-3-amino-4-hydroxybenzoate $(0.01 \mathrm{~mol})$ and an appropriate aryl acid (in excess) was refluxed for $15 \mathrm{hrs}$. The reaction mixture was cooled and poured onto the crushed ice with stirring to obtain the compounds (3a-e)(Ampati et al., 2010).
General procedure for synthesis of 2-substitutedphenyl-1,3benzoxazole-5-carbohydrazides(4a-e)

A mixture of compound (3a) $(0.01 \mathrm{~mol})$, hydrazine hydrate $(99 \%, 0.01 \mathrm{~mol})$ was heated under reflux in absolute ethanol for 15-20 hrs. The reaction mixture was cooled and the solids obtained was filtered and crystallized from ethanol to get white crystalline product (4a).

Similarly other compounds (4b-e) were also prepared by above specified method(Husain et al., 2009).

General procedure for synthesis of $\mathrm{N}$-substitutedphenyl-2-[(2substitutedphenyl-1,3-benzoxazol-5-

\section{yl)carbonyl]hydrazinecarbothioamides (5a-o)}

An alcoholic solution of compound (4a) $(0.002 \mathrm{~mol})$ and substituted phenyl isothiocyanate $(0.002 \mathrm{~mol})$ was refluxed for $2-4$ hrs. The contents were concentrated and poured onto crushed ice, filtered and dried to get hydrazinecarbothiomids (5a).

Similarly other compounds (5b-o) were also prepared by above specified method(Mavrova et al., 2009; Siddiqui et al., 2005).

General procedure for synthesis of 4-substitutedphenyl-5-(2substitutedphenyl-1,3-benzoxazol-5-yl)-2,4-dihydro-3H-1,2,4triazole-3-thiones (6a-o)

A suspension of compound (5a) $(0.002 \mathrm{~mol})$ in ethanol $(25 \mathrm{~mL})$ was dissolved in aqueous sodium hydroxide $(8 \%, 20 \mathrm{~mL})$ and gently refluxed for 5-6 hrs. The resulting solution was concentrated, cooled and filtered. The filtrate was adjusted to $\mathrm{pH}$ 5-6 with diluteacetic acid and was kept aside for $1 \mathrm{hr}$. The crystals produced were filtered, washed with water, dried and recrystallized from ethanol.

The compounds (6b-o) were also synthesized by similar method using reagents in proper mole ratio (Mavrova et al., 2009).

The synthetic route of the compounds is shown in Scheme 1.

4-(2-methylphenyl)-5-(2-phenyl-1,3-benzoxazol-5-yl)-2,4dihydro-3H-1,2,4-triazole-3-thione (6a)

IR $\left(\mathrm{KBr}, \mathrm{cm}^{-1}\right): 3314(\mathrm{NH}), 3002(\mathrm{CH}), 1607(\mathrm{C}=\mathrm{N})$, $1177(\mathrm{C}=\mathrm{S}),{ }^{1} \mathrm{H}-\mathrm{NMR}$ (DMSO-d $\left.{ }_{6}, \delta, \mathrm{ppm}\right): 9.55$ (s, 1H, triazole), 6.89-8.04 (m, 12H, Ar-H), 2.48 (s, 3H, $\mathrm{CH}_{3}$ ), EI-MS: $385(\mathrm{M}+1)$. Anal.calcd for $\mathrm{C}_{22} \mathrm{H}_{16} \mathrm{~N}_{4} \mathrm{OS}: \mathrm{C}, 68.76 ; \mathrm{H}, 4.27 ; \mathrm{N}, 14.45$. Found $\mathrm{C}$, 68.73; H, 4.19; N, 14.57.

\section{4-(3-methylphenyl)-5-(2-phenyl-1,3-benzoxazol-5-yl)-2,4- dihydro-3H-1,2,4-triazole-3- thione (6b)}

IR $\left(\mathrm{KBr}, \mathrm{cm}^{-1}\right): 3315(\mathrm{NH}), 3084(\mathrm{CH}), 1625(\mathrm{C}=\mathrm{N}), 1182$ $(\mathrm{C}=\mathrm{S}) .{ }^{1} \mathrm{H}-\mathrm{NMR}\left(\mathrm{DMSO}-\mathrm{d}_{6}, \delta, \mathrm{ppm}\right): 9.81$ (s, 1H, triazole), 6.58$8.26(\mathrm{~m}, 12 \mathrm{H}, \mathrm{Ar}-\mathrm{H}), 2.40\left(3 \mathrm{H}, \mathrm{s}, \mathrm{CH}_{3}\right)$. Anal.calcd for $\mathrm{C}_{22} \mathrm{H}_{16} \mathrm{~N}_{4} \mathrm{OS}: \mathrm{C}, 68.96 ; \mathrm{H}, 4.01 ; \mathrm{N}, 14.90$; Found C, 68.73; H, $4.19 ; \mathrm{N}, 14.57$. 


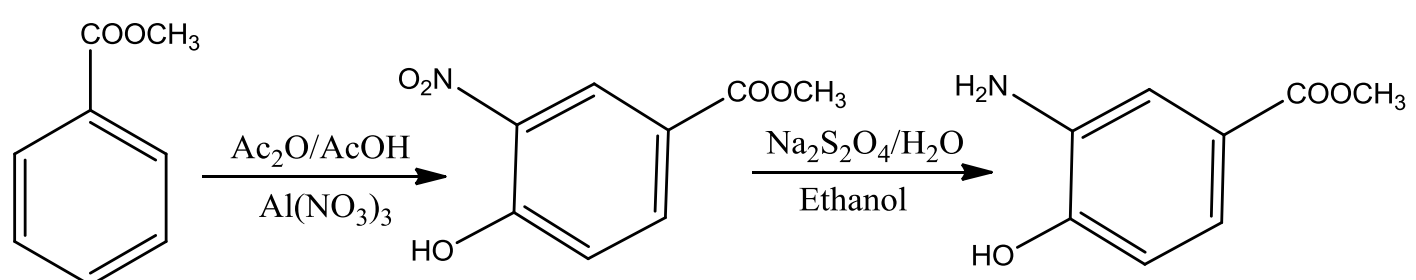

(1)

(2)
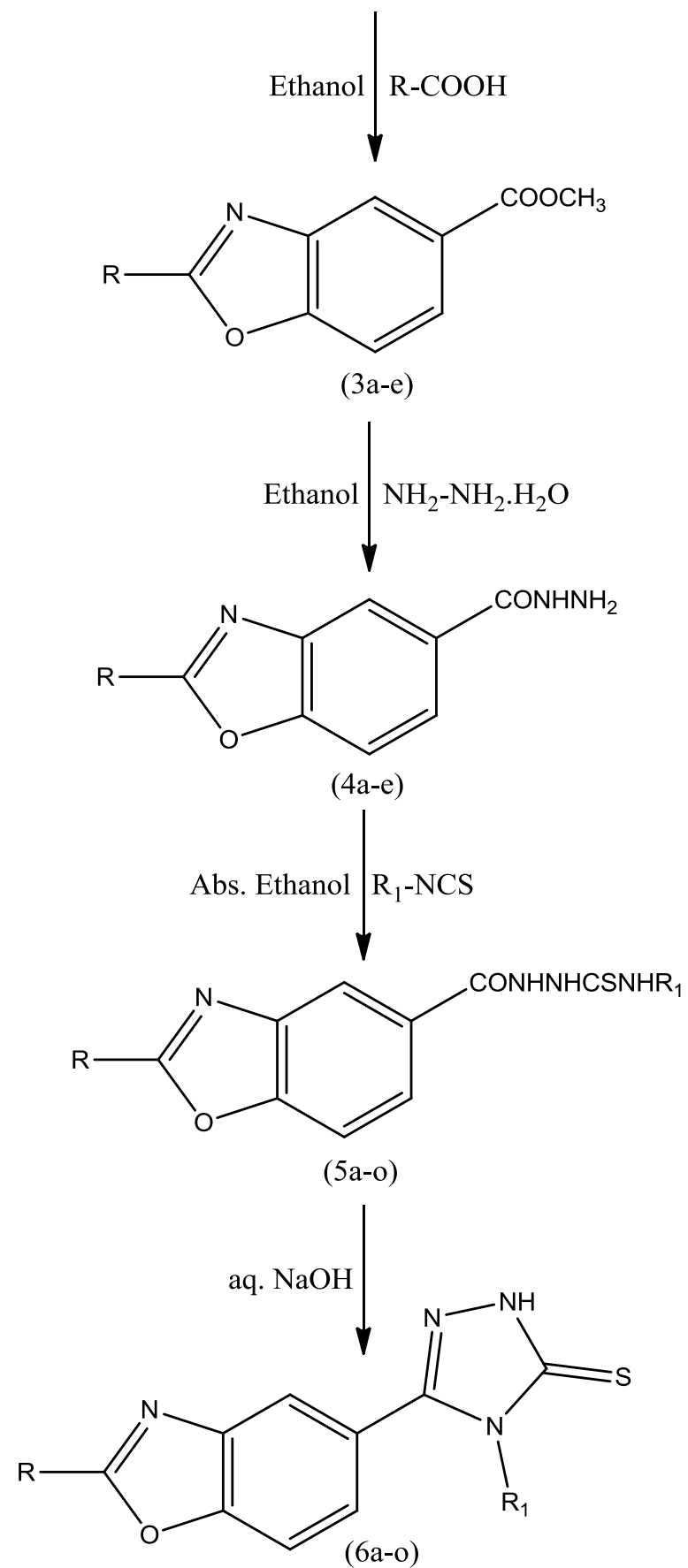

Scheme 1: Synthesis of 4, 5-disubstituted-2, 4 dihydro-3H-1, 2, 4-triazole derivatives (6a-o). 
4-(4-methylphenyl)-5-(2-phenyl-1,3-benzoxazol-5-yl)-2,4dihydro-3H-1,2,4-triazole-3-thione (6c)

IR $\left(\mathrm{KBr}, \mathrm{cm}^{-1}\right): 3314(\mathrm{NH}), 3045(\mathrm{CH}), 1631(\mathrm{C}=\mathrm{N})$, $1228(\mathrm{C}=\mathrm{S}) .{ }^{1} \mathrm{H}-\mathrm{NMR}\left(\mathrm{DMSO}_{6}, \delta, \mathrm{ppm}\right): 9.79(\mathrm{~s}, 1 \mathrm{H}, \mathrm{NH}$, triazole), 7.57-8.87 (m, 12H, Ar-H), $2.49\left(3 \mathrm{H}, \mathrm{s}, \mathrm{CH}_{3}\right)$. EI-MS: $385(\mathrm{M}+1)$. Anal. calcd for $\mathrm{C}_{22} \mathrm{H}_{16} \mathrm{~N}_{4} \mathrm{OS}: \mathrm{C}, 68.96 ; \mathrm{H}, 4.01 ; \mathrm{N}$, 14.90. Found C, 68.73; H, 4.19; N, 14.57.

5-[2-(3-chlorophenyl)-1,3-benzoxazol-5-yl]-4-(2-methylphenyl)2,4-dihydro-3H-1,2,4-triazole-3-thione(6d)

IR $\left(\mathrm{KBr}, \mathrm{cm}^{-1}\right): 3315(\mathrm{NH}), 3053(\mathrm{CH}), 1668(\mathrm{C}=\mathrm{N})$, $1237(\mathrm{C}=\mathrm{S}), 740$ (C-Cl). ${ }^{1} \mathrm{H}-\mathrm{NMR}\left(\mathrm{DMSO}-\mathrm{d}_{6}, \delta, \mathrm{ppm}\right): 9.80$ (s, $1 \mathrm{H}$, $\mathrm{NH}$, triazole), 6.97-7.99 (m, 11H, Ar-H), $2.59\left(\mathrm{~s}, 3 \mathrm{H}, \mathrm{CH}_{3}\right)$. EIMS: $419(\mathrm{M}+1)$. Anal.calcd for $\mathrm{C}_{22} \mathrm{H}_{15} \mathrm{ClN}_{4} \mathrm{OS}: \mathrm{C}, 62.74 ; \mathrm{H}, 3.12$; N, 3.66. Found C, 63.08; H, 3.61; N, 3.37.

5-[2-(3-chlorophenyl)-1,3-benzoxazol-5-yl]-4-(3-methylphenyl)2,4-dihydro-3H-1,2,4-triazole-3-thione (6e)

IR $\left(\mathrm{KBr}, \mathrm{cm}^{-1}\right): 3307(\mathrm{NH}), 3011(\mathrm{CH}), 1634(\mathrm{C}=\mathrm{N})$, $1243(\mathrm{C}=\mathrm{S}), 734(\mathrm{C}-\mathrm{Cl}) .{ }^{1} \mathrm{H}-\mathrm{NMR}$ (DMSO-d $\left.{ }_{6}, \delta, \mathrm{ppm}\right): 9.80$ (s, $1 \mathrm{H}$, triazole), 7.06-8.11 (m, $12 \mathrm{H}, \mathrm{Ar}-\mathrm{H}), 2.60\left(3 \mathrm{H}, \mathrm{s}, \mathrm{CH}_{3}\right)$. Anal.calcd for $\mathrm{C}_{22} \mathrm{H}_{15} \mathrm{ClN}_{4} \mathrm{OS}: \mathrm{C}, 63.50 ; \mathrm{H}, 3.76 ; \mathrm{N}, 3.72$. Found $\mathrm{C}, 63.08 ; \mathrm{H}$, $3.61 ; \mathrm{N}, 3.37$.

5-[2-(3-chlorophenyl)-1,3-benzoxazol-5-yl]-4-(4-methylphenyl)2,4-dihydro-3H-1,2,4-triazole-3-thione (6f)

IR $\left(\mathrm{KBr}, \mathrm{cm}^{-1}\right): 3307(\mathrm{NH}), 3007(\mathrm{CH}), 1649(\mathrm{C}=\mathrm{N})$, $1275(\mathrm{C}=\mathrm{S}), 726(\mathrm{C}-\mathrm{Cl}) .{ }^{1} \mathrm{H}-\mathrm{NMR}$ (DMSO-d $\left.{ }_{6}, \delta, \mathrm{ppm}\right): 9.77$ (s, $1 \mathrm{H}$, triazole), 6.76-8.01 (m, $12 \mathrm{H}, \mathrm{Ar}-\mathrm{H}), 2.53\left(3 \mathrm{H}, \mathrm{s}, \mathrm{CH}_{3}\right)$.Anal.calcd for $\mathrm{C}_{22} \mathrm{H}_{15} \mathrm{ClN}_{4} \mathrm{OS}: \mathrm{C}, 63.00 ; \mathrm{H}, 3.21 ; \mathrm{N}, 3.00$. Found $\mathrm{C}, 63.08 ; \mathrm{H}$, $3.61 ; \mathrm{N}, 3.37$.

5-[2-(4-chlorophenyl)-1,3-benzoxazol-5-yl]-4-(2-methylphenyl)2,4-dihydro-3H-1,2,4-triazole-3-thione (6g)

IR $\left(\mathrm{KBr}, \mathrm{cm}^{-1}\right): 3289(\mathrm{NH}), 3085(\mathrm{CH}), 1600(\mathrm{C}=\mathrm{N})$, $1246(\mathrm{C}=\mathrm{S}), 741(\mathrm{C}-\mathrm{Cl}) .{ }^{1} \mathrm{H}-\mathrm{NMR}\left(\mathrm{DMSO}^{-} \mathrm{d}_{6}, \delta, \mathrm{ppm}\right): 9.40$ (s, $1 \mathrm{H}, \quad$ triazole $), \quad 7.04-8.20 \quad(\mathrm{~m}, \quad 12 \mathrm{H}, \quad$ Ar- $\mathrm{H}), 2.61 \quad(3 \mathrm{H}, \mathrm{s}$, $\mathrm{CH}_{3}$ ).Anal.calcd for $\mathrm{C}_{22} \mathrm{H}_{15} \mathrm{ClN}_{4} \mathrm{OS}: \mathrm{C}, 63.00 ; \mathrm{H}, 3.21 ; \mathrm{N}, 3.00$. Found C, 63.08; H, 3.61; N, 3.37.

\section{5-[2-(4-chlorophenyl)-1,3-benzoxazol-5-yl]-4-(3-methylphenyl)-} 2,4-dihydro-3H-1,2,4-triazole-3-thione (6h)

IR $\left(\mathrm{KBr}, \mathrm{cm}^{-1}\right): 3390(\mathrm{NH}), 3011(\mathrm{CH}), 1596(\mathrm{C}=\mathrm{N})$, $1243(\mathrm{C}=\mathrm{S}), 702(\mathrm{C}-\mathrm{Cl}) .{ }^{1} \mathrm{H}-\mathrm{NMR}$ (DMSO-d $\left.{ }_{6}, \delta, \mathrm{ppm}\right): 9.55(\mathrm{~s}, 1 \mathrm{H}$, triazole), 6.86-7.26 (m, 12H, Ar-H), $2.59\left(3 \mathrm{H}, \mathrm{s}, \mathrm{CH}_{3}\right)$. EI-MS: $419(\mathrm{M}+1)$. Anal.calcd for $\mathrm{C}_{22} \mathrm{H}_{15} \mathrm{ClN}_{4} \mathrm{OS}: \mathrm{C}, 63.15 ; \mathrm{H}, 3.98 ; \mathrm{N}$, 3.74. Found C, 63.08; H, 3.61; N, 3.37.

\section{5-[2-(4-chlorophenyl)-1,3-benzoxazol-5-yl]-4-(4-methylphenyl)-}

2,4-dihydro-3H-1,2,4-triazole-3-thione (6i)

IR $\left(\mathrm{KBr}, \mathrm{cm}^{-1}\right): 3330(\mathrm{NH}), 3058(\mathrm{CH}), 1633(\mathrm{C}=\mathrm{N})$, $1243(\mathrm{C}=\mathrm{S}), 736(\mathrm{C}-\mathrm{Cl}) .{ }^{1} \mathrm{H}-\mathrm{NMR}$ (DMSO-d $\left.{ }_{6}, \delta, \mathrm{ppm}\right): 9.41(\mathrm{~s}, 1 \mathrm{H}$, triazole), 7.00-7.98 (m, 12H, Ar-H), $2.88\left(3 \mathrm{H}, \mathrm{s}, \mathrm{CH}_{3}\right)$. Anal.calcd for $\mathrm{C}_{22} \mathrm{H}_{15} \mathrm{ClN}_{4} \mathrm{OS}$ : C, 63.45; H, 3.77; N, 3.66. Found C, 63.08; H, $3.61 ; \mathrm{N} 3.37$.

5-[2-(3-bromophenyl)-1,3-benzoxazol-5-yl]-4-(2-methylphenyl)2,4-dihydro-3H-1,2,4-triazole-3-thione(6j)

IR $\left(\mathrm{KBr}, \mathrm{cm}^{-1}\right): 3327(\mathrm{NH}), 3017(\mathrm{CH}), 1574(\mathrm{C}=\mathrm{N})$, 1234(C=S),539 (C-Br). ${ }^{1} \mathrm{H}-\mathrm{NMR}$ (DMSO-d 6 , $\left.\delta, \mathrm{ppm}\right): 9.44$ (s, 1H, triazole), 6.77-7.04 (m, 12H, Ar-H), $2.34\left(3 \mathrm{H}, \mathrm{s}, \mathrm{CH}_{3}\right)$.Anal.calcd for $\mathrm{C}_{22} \mathrm{H}_{15} \mathrm{BrN}_{4} \mathrm{OS}$ : C, 56.89; H, 3.09; N, 12.45. Found C, 57.03; $\mathrm{H}, 3.26 ; \mathrm{N}, 12.09$.

5-[2-(3-bromophenyl)-1,3-benzoxazol-5-yl]-4-(3-methylphenyl)2,4-dihydro-3H-1,2,4-triazole-3-thione (6k)

IR $\left(\mathrm{KBr}, \mathrm{cm}^{-1}\right): 3364(\mathrm{NH}), 3092(\mathrm{CH}), 1595(\mathrm{C}=\mathrm{N})$, $1248(\mathrm{C}=\mathrm{S}), 533(\mathrm{C}-\mathrm{Br}) .{ }^{1} \mathrm{H}-\mathrm{NMR}\left(\mathrm{DMSO}-\mathrm{d}_{6}, \delta, \mathrm{ppm}\right): 9.00(\mathrm{~s}$, $1 \mathrm{H}$, triazole), 6.99-8.00 (m, 12H, Ar-H), $2.77\left(3 \mathrm{H}, \mathrm{s}, \mathrm{CH}_{3}\right)$. EI-MS: $464(\mathrm{M}+1)$. Anal.calcd for $\mathrm{C}_{22} \mathrm{H}_{15} \mathrm{BrN}_{4} \mathrm{OS}: \mathrm{C}, 56.43 ; \mathrm{H}, 3.44 ; \mathrm{N}$, 11.90. Found C, 57.03; H, 3.26; N 12.09 .

\section{5-[2-(3-bromophenyl)-1,3-benzoxazol-5-yl]-4-(4-methylphenyl)- \\ 2,4-dihydro-3H-1,2,4-triazole-3-thione (6l)}

IR $\left(\mathrm{KBr}, \mathrm{cm}^{-1}\right): 3316(\mathrm{NH}), 3088(\mathrm{CH}), 1527(\mathrm{C}=\mathrm{N})$, $1249(\mathrm{C}=\mathrm{S}), 563(\mathrm{C}-\mathrm{Br}) .{ }^{1} \mathrm{H}-\mathrm{NMR}$ (DMSO-d $\left.{ }_{6}, \delta, \mathrm{ppm}\right): 9.81$ (s, $1 \mathrm{H}, \quad$ triazole $), \quad 6.58-8.26(\mathrm{~m}, \quad 12 \mathrm{H}, \quad$ Ar- $\mathrm{H}), 2.48(3 \mathrm{H}, \quad \mathrm{s}$, $\mathrm{CH}_{3}$ ).Anal.calcd for $\mathrm{C}_{22} \mathrm{H}_{15} \mathrm{BrN}_{4} \mathrm{OS}: \mathrm{C}, 56.71 ; \mathrm{H}, 3.35 ; \mathrm{N}, 12.40$. Found C, 57.03; H, 3.26; N, 12.09 .

\section{5-[2-(4-bromophenyl)-1,3-benzoxazol-5-yl]-4-(2-methylphenyl)-} 2,4-dihydro-3H-1,2,4-triazole-3-thione (6m)

IR $\left(\mathrm{KBr}, \mathrm{cm}^{-1}\right): 3319(\mathrm{NH}), 2980(\mathrm{CH}), 1593(\mathrm{C}=\mathrm{N})$, $1212(\mathrm{C}=\mathrm{S}), 533(\mathrm{C}-\mathrm{Br}) .{ }^{1} \mathrm{H}-\mathrm{NMR}\left(\mathrm{DMSO}_{-} \mathrm{d}_{6}, \delta, \mathrm{ppm}\right): 9.51(\mathrm{~s}$, $1 \mathrm{H}$, triazole), 6.10-8.01 (m, $12 \mathrm{H}, \mathrm{Ar}-\mathrm{H}), 2.55\left(3 \mathrm{H}, \mathrm{s}, \mathrm{CH}_{3}\right)$. EI-MS: $464(\mathrm{M}+1)$. Anal.calcd for $\mathrm{C}_{22} \mathrm{H}_{15} \mathrm{BrN}_{4} \mathrm{OS}: \mathrm{C}, 57.39 ; \mathrm{H}, 2.90 ; \mathrm{N}$, 12.18. Found C, 57.03; H, 3.26; N 12.09.

\section{5-[2-(4-bromophenyl)-1,3-benzoxazol-5-yl]-4-(3-methylphenyl)- 2,4-dihydro-3H-1,2,4-triazole-3-thione (6n)}

IR $\left(\mathrm{KBr}, \mathrm{cm}^{-1}\right): 3318(\mathrm{NH}), 3029(\mathrm{CH}), 1599(\mathrm{C}=\mathrm{N})$, $1212(\mathrm{C}=\mathrm{S}), 547(\mathrm{C}-\mathrm{Br}) .{ }^{1} \mathrm{H}-\mathrm{NMR}\left(\mathrm{DMSO}_{-} \mathrm{d}_{6}, \delta, \mathrm{ppm}\right): 9.43(\mathrm{~s}$, $1 \mathrm{H}, \quad$ triazole $), \quad 6.07-7.97(\mathrm{~m}, \quad 12 \mathrm{H}, \quad \mathrm{Ar}-\mathrm{H}), 2.57(3 \mathrm{H}, \mathrm{s}$, $\mathrm{CH}_{3}$ ).Anal.calcd for $\mathrm{C}_{22} \mathrm{H}_{15} \mathrm{BrN}_{4} \mathrm{OS}: \mathrm{C}, 57.29 ; \mathrm{H}, 3.56 ; \mathrm{N}, 11.79$. Found C, 57.03; H, 3.26; N, 12.09 .

\section{5-[2-(4-bromophenyl)-1,3-benzoxazol-5-yl]-4-(4-methylphenyl)- 2,4-dihydro-3H-1,2,4-triazole-3-thione (6o) \\ IR $\left(\mathrm{KBr}, \mathrm{cm}^{-1}\right): 3380(\mathrm{NH}), 3056(\mathrm{CH}), 1600(\mathrm{C}=\mathrm{N})$,} $1244(\mathrm{C}=\mathrm{S}), 533(\mathrm{C}-\mathrm{Br}) .{ }^{1} \mathrm{H}-\mathrm{NMR}$ (DMSO-d $\left.{ }_{6}, \delta, \mathrm{ppm}\right): 9.66(\mathrm{~s}$, $1 \mathrm{H}$, triazole), 6.14-8.11 (m, 12H, Ar-H), $2.71\left(3 \mathrm{H}, \mathrm{s}, \mathrm{CH}_{3}\right)$. EI-MS: $464(\mathrm{M}+1)$. Anal.calcd for $\mathrm{C}_{22} \mathrm{H}_{15} \mathrm{BrN}_{4} \mathrm{OS}: \mathrm{C}, 56.89 ; \mathrm{H}, 3.01 ; \mathrm{N}$, 12.33. Found C, 57.03; H, 3.26; N 12.09 .

\section{ANTICONVULSANT SCREENING}

The anticonvulsant screening of the synthesized compounds were performed according to the standard protocol 
provided by epilepsy branch of the National Institute of Neurological Disorders and Stroke (NINDS) following the protocol adopted by Antiepileptic Drug Development (ADD) program (Krall et al., 1978; Stables et al., 1997; Kupferberg et al., 1998). Swiss albino mice (20-25gm) of either sex were used as experimental animals. All experimental protocols were carried out with permission from the Institutional Animal Ethics Committee (IAEC).

Animals were obtained from the Central Animal House Facility, Jamia Hamdard University, New Delhi, India. The mice were kept under standard conditions at an ambient temperature of $25 \pm 2{ }^{\circ} \mathrm{C}$ and allowed free access to food and water except at the time they were brought out of the cage. The synthesized compounds were suspended in polyethylene glycol (PEG-400).

\section{Maximal electroshock test (MES)}

The anticonvulsant activity in MES test was indicated by the lower dose which protected the hind limb tonic extension in more than half of the animals. Each animal received i.p. injection of the test compounds $(30 / 100 / 300 \mathrm{mg} / \mathrm{kg})$ followed by electroshock with $60 \mathrm{~Hz}$ of $50 \mathrm{~mA}$ for $0.2 \mathrm{sec}$ via ear clip electrode through electroconvulsometer as per the reported procedure and activity was assessed at 0.5 and 4 hrs after administration (Krall et al., 1978; Porter et al., 1984).

\section{Subcutaneous pentylenetetrazole seizure test (scPTZ)}

The subcutaneous pentylenetetrazole test was performed according to the known protocol (Swinyard et al., 1989; Chen et al., 2007; Kucukguzel et al., 2004). Subcutaneous injection of the pentylenetetrazole produces clonic seizures in laboratory animals. It detects the ability of test compounds to raise the seizure threshold of an animal and thus protect it from exhibiting a clonic seizure. Animals were pretreated with various doses of the test compound given by i.p. injection. The dose of pentylenetetrazole $(75 \mathrm{mg} / \mathrm{kg})$ which induces convulsions in $>95 \%$ of animals is injected into a loose fold of the skin in the midline of the neck. The animals were placed in isolation cages to minimize stress and observed for the next $30 \mathrm{~min}$ for the presence or absence of a seizure. Failure to observe even a threshold seizure (a single episode of clonic spasms of at least $5 \mathrm{sec}$ duration) was defined as protection.

\section{Neurotoxicity screening}

To assess a compound's undesirable side effects (toxicity), animals are monitored for overt signs of impaired neurological or muscular function. In mice, the rotarod procedure (Dunham and Miya, 1957; Kucukguzel et al., 2004) is used to disclose minimal muscular or neurological impairment. The mice were trained to stay on an accelerating rotarod that rotated at $6 \mathrm{rpm}$ and its diameter was $3.2 \mathrm{~cm}$. Only those mice were taken for the test which could stay on the revolving rod for at least one minute. Trained animals were injected i.p. with the test compounds at doses of $300 \mathrm{mg} / \mathrm{kg}$. The inability of the animal to maintain equilibration on the rod for at least one minute indicated neurotoxicity.

\section{Log $P$ determination}

Log $P$ (partition coefficient) is an imperative physicochemical marker of drug permeability across the blood brain barrier for an inadequate drug concentration in crucial brain areas (Kwan and Brodie, 2005). Pharmacological activity is dependent on the lipophilic character of the drug. Anticonvulsant activities of different type of compounds were correlated with lipophilicity (Lien et al., 1979).However, it has been observed that the maximum potency of the drugs which act on the central nervous system is obtained with congeners having an optimum lipophilicity $(\log P)$ near 2 . In general the optimal hydrophobicity $(\log P \approx 2$ ) of the molecules is essential for anticonvulsant activity without any neurotoxicity. Therefore, partition coefficient of all the compounds were determined by the procedure described in the literature (Farrar et al., 1993) and to establish the correlation between $\log P$ and anticonvulsant activity.

\section{RESULTS AND DISCUSSION}

The synthetic route used to synthesize title compounds is outlined in Scheme 1. The methyl- 3-amino-4-hydroxybenzoate (2) was prepared according to the method reported in the literature (Gopalakrishna et al., 2005). The methyl-3-amino-4hydroxybenzoate underwent cyclization with an appropriate aryl acids to afford methyl-2-substitutedphenyl-1,3-benzoxazole-5carboxylates (3a-e). Furthermore, reaction of methyl 2substitutedphenyl-1,3-benzoxazole-5-carboxylates with hydrazine hydrate followed by treatment with substituted arylisothiocyanates resulted in the formation of hydrazinecarbothioamides (5ao).Finally, hydrazinecarbothioamides were cyclized with an aqueous solution of sodium hydroxide to give the titled compounds (6a-o), was confirmed by appearance of a singlet at around $9.80 \mathrm{ppm}$ due to $-\mathrm{NH}$ proton of triazole ring and absence of a singlet at around 10.27 and $8.67 \mathrm{ppm}$ attributed to $-\mathrm{CONH}-$ and $-\mathrm{NHCSNH}-$ protons of hydrazinecarbothioamides respectively. In all the cases the TLC of the product showed the single spot confirming the chromatogram for only one product. The chemical structures of the synthesized compounds were established by elemental analysis and spectral data results are reported in experimental protocols. The elemental analysis results were within $\pm 0.4 \%$ of the theoretical values.

The preliminary anticonvulsant activity of the target compounds (6a-o) were determined according to the phase I tests of the Antiepileptic Drug Development (ADD) program. ADD program was developed by National Institute of Neurological Disorders and Stroke (NINDS) and it includes the subcutaneous pentylenetetrazole (Swinyard et al., 1989) and themaximal electroshock seizure screen (Porter et al., 1984). scPTZ and MES screens are considered as the "gold standard" seizure model screens where they are used to identify compounds that elevate seizure threshold and to indicate the ability of the test prevent 
seizure spread, respectively. Additionally, acute toxicity from antiepileptic drugs in rodents is almost invariably manifested by neurological deficits. These include sedation, altered motor activity, ataxia, and impaired righting reflexes. These effects of antiepileptic drugs are often summarized by the term "neurotoxicity." Minimal neurological deficit, such as impaired motor function, can be detected by standardized test, that is, by the rotarod test (Dunham and Miya, 1957). Data is presented in Table 2 after the 0.5 and 4 hrs time intervals at the dose level of 30, 100 and $300 \mathrm{mg} / \mathrm{kg}$. Phenytoin and carbamazepine were used as the standard drugs for the comparison.

Maximal electroshock seizure test is a proven method to check the hind limb tonic extension seizure and identifies clinical candidates that prevent seizure spread. All the compounds except $6 \mathrm{a}$ and $6 \mathrm{c}$ were found to exhibit protection in both MES and scPTZ tests making them useful for broad spectrum of seizure types. Compounds that showed protection against MES model at 100 $\mathrm{mg} / \mathrm{kg}$ include $6 \mathrm{~d}, 6 \mathrm{f}, 6 \mathrm{i}, 6 \mathrm{j}, 6 \mathrm{k}, 6 \mathrm{n}$ and 6o. Compounds $6 \mathrm{~d}, 6 \mathrm{f}, 6 \mathrm{~g}$, $6 \mathrm{~h}, 6 \mathrm{i}, 6 \mathrm{j}, 6 \mathrm{k}, 6 \mathrm{~m}, 6 \mathrm{n}$ and $6 \mathrm{o}$ showed activity both at 0.5 and 4.0 hrs. Thus, only three compounds $6 \mathrm{~g}$, $6 \mathrm{~h}$ and $6 \mathrm{~m}$ showing activity at a lower dose of $30 \mathrm{mg} / \mathrm{kg}$ seems to be very potent in anticonvulsant MES screening. Some of the compounds showed activity only at $0.5 \mathrm{~h}$, indicating that they have rapid onset and shorter duration of action.

Insc PTZ screening, all the compounds except $6 \mathrm{a}, 6 \mathrm{c}$ and 6e showed activity indicative of their ability to prevent seizure spread. Compounds 6b, 6d, 6f, 6g, 6k and 61 showed 100\% protection at a dose of $300 \mathrm{mg} / \mathrm{kg}$ at $0.5 \mathrm{~h}$. So these compounds have quick onset but for shorter duration of action. Some compounds (6i, 6j, 6m and 6n) were also active after $4.0 \mathrm{hrs}$ extended period of activity. Only two compounds $6 \mathrm{~h}$ and 60 showed activity at the dose level of $300 \mathrm{mg} / \mathrm{kg}$ at both time intervals.

In the neurotoxicity screening, compounds $6 \mathrm{~g}, 6 \mathrm{~h}, 6 \mathrm{i}, 6 \mathrm{k}$ and $6 \mathrm{~m}$ do not show any toxicity at the dose of $300 \mathrm{mg} / \mathrm{kg}$. Compounds 6jand 6o were toxic at 0.5 and 4.0 hrs., whereas three compounds $6 \mathrm{~b}, 6 \mathrm{e}$ and $6 \mathrm{f}$ showed toxicity after $0.5 \mathrm{~h}$ and do not show toxicity after 4.0 hrs. Three compounds (6d, 61 and $6 \mathrm{n}$ ) showed delayed toxicity i.e., toxicity only after $4.0 \mathrm{hrs}$, which is comparable with that of carbamazepine $(300 \mathrm{mg} / \mathrm{kg})$. However, all the compounds were less toxic than phenytoin $(100 \mathrm{mg} / \mathrm{kg})$. There have been several attempts to provide insight into pharmacophore modeling of the putative MES receptor showing several common structural features essential for activity. Although, the chemical diversity and various mechanisms of action of anticonvulsants make it difficult to identify a common pharmacophore, the essential structural elements in the four-point pharmacophore model were assumed as lipophilic aryl ring center $(\mathrm{A}),=\mathrm{N}-$ as an electron donor atom (D), $-\mathrm{NHC}=\mathrm{S}$ as a hydrogen-bonding domain (HBD) and another hydrophobic aryl ring (C) responsible for metabolism (Figure 2) (Unverferth et al., 1998). All the molecules are 3D optimized and were conformers which bring the abovementioned groups closely together. Partition coefficient is an imperative physicochemical marker of drug permeability across the blood brain barrier (BBB) for an inadequate drug concentration in crucial brain areas (Kwan and Brodie 2005). Therefore, partition coefficients of all the compounds were determined to establish the correlation between $\log \mathrm{P}$ and anticonvulsant activity. Compounds $6 \mathrm{~d}, 6 \mathrm{f}, 6 \mathrm{~g}, 6 \mathrm{~h}, 6 \mathrm{i}, 6 \mathrm{j}, 6 \mathrm{k}, 6 \mathrm{~m}, 6 \mathrm{n}$ and $6 \mathrm{o}$ were found to be more lipophilic having potent anticonvulsant activity. The other compounds $6 \mathrm{e}$ and 61 were also lipophilic having some potency. Compounds $6 \mathrm{a}, 6 \mathrm{~b}$ and $6 \mathrm{c}$ were less lipophilic and were less active in MES test.

On correlating the structures of the sample candidate with their biological activities, it has been observed that, out of various phenyl substituted derivatives, three compounds $(6 \mathrm{~g}, 6 \mathrm{~h}$ and $6 \mathrm{~m}$ ) have significance toward both MES and scPTZ activities (30 and $300 \mathrm{mg} / \mathrm{kg}$ ). The nature of the substituted group onthe phenyl ring appeared to greatly influence the antiepileptic activity. On analyzing the antiepileptic activity of all the compounds, the following SAR was gained. Presence of halogens at para position greatly increased antiepileptic activity. Among halogen analogs chloro derivatives exhibited better activity followed by bromo, whereas the presence of a methyl substituent showed moderate activity and unsubstituted derivatives exhibited least activity.

\section{CONCLUSION}

A series of 4, 5-disubstituted-1,2,4-triazoles were synthesized and characterized by spectral techniques. The compounds were subjected to antiepileptic screening by standard methods with drug phenytoin and carbamazepine as standards. All the compounds except $6 \mathrm{a}$ and $6 \mathrm{c}$ were found to exhibit protection in both MES and scPTZ tests making them useful for broad spectrum of seizure types. The triazole derivatives displayed moderate to good anticonvulsant activity. Here the activity is attributed to the presence of favorable structural environment such as aryl binding site with a hydrophobic group, hydrogen bonding domain group, electron donor, electron withdrawing group and another hydrophobic aryl ring. Rather increase in the hydrophobicity in the synthesized molecules brings about same degree of activity in the series. The compounds $6 \mathrm{~g}$, $6 \mathrm{~h}$ and $6 \mathrm{~m}$ found to be the most promising analogs displaying protection in MES model without neurotoxicity and emerged as lead in these series. Further, the $6 \mathrm{~d}, 6 \mathrm{f}, 6 \mathrm{i}, 6 \mathrm{j}, 6 \mathrm{k}, 6 \mathrm{n}$ and $6 \mathrm{o}$ come out as potential candidates for further investigation. Some compounds (6d, 6f, 6g, 6h, 6i, 6j, 6k, 6m, 6n and 6o) showed more lipophilic character and were more active. The compounds $6 \mathrm{e}$ and 61 were also lipophilic but were less active in MES test. Finally, it can be readily conclude that the substitution pattern in the phenyl ring influences the activity as well astoxicity of the different substituted triazoles.

\section{ACKNOWLEDGMENT}

Authors are highly thankful to Managing Director "Sharda University", for providing the research facilities in School of Pharmacy, Department of Pharmaceutical Chemistry, Greater Noida, Uttar Pradesh. The authors are really grateful to IIT Delhi 
and Faculty of pharmacy, Jamia Hamdard, New Delhi, India, for providing the spectral analysis of the compounds. We are also thankful to Antiepileptic drug development (ADD) Programme, Epilepsy Branch, National Institute of Health (NIH), USA, for carrying out the anticonvulsant activity test.

\section{Financial support and sponsorship: Nil.}

Conflict of Interests: There are no conflicts of interest.

\section{REFERENCES}

Ampati S, Jukanti R, Sagar V, Ganta R, Manda S. Synthesis and in vivo anti-inflammatory activity of a novel series of benzoxazole derivatives. Der Chem Sin, 2010; 1(3):157-168.

Bell GS, Sander JW. The epidemiology of epilepsy: The size of the problem. Seizure, 2002; 11(Suppl.A):306-314.

Blum DE. New drugs for persons with epilepsy. Adv Neurol, 1998; 76: 57-87.

Brittonm JW, So EL, New antiepileptic drugs: prospects for the future. J Epilep, 1995; 8: 267-281.

Chai B, Qian X, Cao S, Liu H, Song G. Synthesis and insecticidal activity of 1,2,4-triazole derivatives. ArchOrg Chem, 2003;2:141-145.

Chen J, Sun XY, Chai KY, Lee JS, Song MS, Quan ZS. Synthesis and anticonvulsant evaluation of 4-(4-alkoxylphenyl)-3-ethyl$4 \mathrm{H}-1,2,4$-triazoles as open-chain analogues of 7-alkoxyl-4,5dihydro[1,2,4]triazolo[4,3-a]quinolines.Bioorg Med Chem, 2007;15:67756781.

Daras MD, Bladin PF, Eadie MJ, Millet D, 2007. Epilepsy: historical perspectives, in: Engel J, Pedley T. second ed., Epilepsy: A Comprehensive Textbook, Vol. 1 Lippincott Williams and Wilkins, Philadelphia13-15.

Dimmock JR, Pandeya SN, Quail JW, Pugazhenthi U, Allen TM, Kao GY, Balzarini J, De Clercq E. Evaluation of the semicarbazones, thiosemicarbazones and biscarbohydrazones of some aryl alicyclic ketones for anticonvulsant and other biological properties. Eur J Med Chem, 1995;30:303-314.

Dimmock JR, Vashishtha SC, Stables JP. Anticonvulsant properties of various acetylhydrazones, oxamoylhydrazones and semicarbazones derived from aromatic and unsaturated carbonyl compounds. Eur J Med Chem, 2000a;35:241-248.

Dimmock JR, Vashishtha SC, Stables JP.Ureylene anticonvulsants and related compounds.Pharmazie, 2000b;55:490-494.

Dunham NW, Miya TS.A note on a simple apparatus for detecting neurological deficit in rat and mice. J Am Pharm AssoSci, 1957;46:208-209.

Farrar VA, Ciechanowicz-Rutkowska M, Grochowski J,Serda P, Pilati T, Filippini G, Hinko CN, El-Assadi A, Moore JA, Edafiogho IO, Andrews CW, Cory M, Nicholson JM, Scott KR. Synthesis and CLOGP correlation of imidooxy anticonvulsants.J Med Chem, 1993;36:3517-3525.

Gibson A, Harkless J, Alexander M, Scott KR. Enaminones 10. Molecular modeling aspects of the 5-methylcyclohexenone derivatives.Bioorg Med Chem, 2009;17:5342-5346.

Gopalakrishna B, Rao VJ, Bari S, Venkatesham A, Sarangapani M, Raghunandan N. Synthesis and anti-inflammatory activity of some new benzoxazole Schiff bases. Ind Drug, 2005;6:369-374.

Gumrukcuoglu N, Bekircan O, Serdar M, Celik E, Sevim A, Demirbas N. Synthesis and antimicrobial activities of some new 1,2,4triazole derivatives. Turk J Chem, 2007;31:335-348.

Guzeldemirci NU, Kucukbasmaci O. Synthesis and antimicrobial activity evaluation of new 1,2,4-triazoles and 1,3,4thiadiazoles bearing imidazo[2,1-b]thiazole moiety. Eur J Med Chem, 2010;4:63-68.

Husain A, Naseer MA, Sarafroz M. Synthesis and anticonvulsant activity of some novel fused heterocyclic 1,2,4-triazolo- [3,4-b]-1,3,4-thiadiazole derivatives. Acta Pol Pharm Drug Res, 2009;66:135-140.

Husain A, Siddiqui N, Sarafroz M, Khatoon Y, Rasid M, Ahmad N. Synthesis, anticonvulsant and neurotoxicity screening of some novel 1,2,4-trisubstituted-1H-imidazole derivatives.Acta PolPharm Drug Res, 2011;68:657-663.

Kaushik D, Khan SA, Chawla G, Kumar S. N'-[(5-chloro-3methyl-1-phenyl-1H-pyrazol-4-yl)methylene]2/4-substituted hydrazides: synthesis and anticonvulsant activity. Eur J Med Chem, 2010;45:39433949.

Klimesova V, Zahajska L, Waisser K, Kaustova J, Mollmann U. Synthesis and antimycobacterial activity of 1,2,4-triazole 3-benzylsulfanyl derivatives. I L Farma, 2004; 59: 279-288.

Korczyn AD, Schachter SC, Amlerova J, Bialer M, van Emde Boas W, Brazdil M, Brodtkorb E, Engel JJr, GotmanJ, KomarekV, LeppikIE, MarusicP, Meletti S, Metternich B, Moulin CJ, Muhlert N, Mula M, Nakken KO, Picard F, Schulze-Bonhage A, Theodore W, Wolf P, Zeman A, Rektor I. Third International Congress on Epilepsy, Brain and Mind: Part 1. EpilBehav, 2015;50:116-137.

Krall RL, Penry JK, White BG, Kupferberg HJ, Swinyard EA. Antiepileptic drug development: II. Anticonvulsant drug screening.Epilepsia, 1978;19:409-428.

Kucukguzel I, Kucukguzel SG, Rollas S, Sanis GO, Ozdemir O, Bayrak I, Altug T, Stables JP. 3-(aryl alkyl thio)-4-alkyl/aryl-5-(4aminophenyl)-4h-1,2,4-triazole derivatives and their anticonvulsant activity. I L Farma, 2004;59:893-901.

Kumar H, Javed SA, Khan SA, Amir M. 1,3,4Oxadiazole/thiadiazole and 1,2,4-triazole derivatives of biphenyl-4-yloxy acetic acid: synthesis and preliminary evaluation of biological properties.Eur J Med Chem, 2008;43:2688-2698.

Kupferberg HJ, Stables JP. in: Stefan H, Kramer G, Mamoli B. 1998. Challenge epilepsy new anticonvulsant drugs, Boston MA: Blackwell Science Ltd 7-29.

Kwan P, Brodie MJ. Potential role of drug transporters in the pathogenesis of medically intractable epilepsy.Epilepsia, 2005;46:224235 .

Kwan P, Brodie MJ. Early identification of refractory epilepsy.N Engl J Med, 2000;342:314-319.

Li Y, LiangJ, Siu T, Hu E, RossiMA, Barnett SF,DefeoJonesD, Jones RE, Robinson RG, Leander K, Huber HE, Mittal S, Cosford N, Prasit P.Allosteric inhibitors of Akt1 and Akt2: discovery of $[1,2,4]$ triazolo[3,4-f][1,6]naphthyridines with potent and balanced activity.Bioorg Med Chem Lett, 2009;19:834-836.

Lien EJ, Liuo RCH, Shinoucla HG.Quantitative structureactivity relationships and dipole moments of anticonvulsants and CNS depressants. J Pharm Sci, 1979;68:463-468.

Loscher W. New visions in the pharmacology of anticonvulsion.Eur J Pharmacol, 1998;342:1-3.

Ma Y, Liu R, Gong X, Li Z, Huang Q, Wang H, Song GG. Synthesis and herbicidal activity of N,N-diethyl-3-(arylselenonyl)-1H1,2,4-triazole-1-carboxamide. J Agric Food Chem, 2006;54:7724-7728.

Mavrova AT, Wesselinova D, Tsenov YA, Denkova P. Synthesis, cytotoxicity and effects of some 1,2,4-triazole and 1,3,4thiadiazole derivatives on immunocompetent cells. Eur J Med Chem, 2009;44:63-69.

McNamara JO. Emerging insights into the genesis of epilepsy. Nature, 1999;399:A15-22.

Nagai SI, Ueda T, Sugiura S, Nagatsu A, Murakami N, Sakakibara J. Fujita M, Hotta Y. Synthesis and central nervous system stimulant activity of 5,8-methanoquinazolines fused with 1,2,4-triazole, tetrazoleand 1,2,4-triazine. J Het Chem, 1998;35:325-327.

Njamnshi AK, Bissek ACZK, Yepnjio FN, Tabah EN, Angwafor SA, Kuate CT, Dema F, Fonsah JY, Acho A, Kepeden MN, Azinwi YH, Kuwoh PB, Angwafor FF, Muna WF. A community survey of knowledge perceptions and practice with respect to epilepsy among traditional healers in the Batibo Health District, Cameron.EpilepBehav, 2010;17:95-102. 
Pandeya SN, Raja AS, Stables JP.Synthesis of isatinsemicarbazones as novel anticonvulsants - role of hydrogen bonding. J PharmPharmSci, 2002;5:266-271.

Porter RJ, Cereghino JJ, Gladding GD, Hessie BJ, Kupferberg HJ, Scoville B, White BG. Antiepileptic drug development program. Cleve Clin Q, 1984;51:293-305.

Sabers A, Gram L. Newer anticonvulsants comparative review of drug interactions and adverse effects. Drugs, 2000;60:23-33.

Salgın-Goksen U, Gokhan-Kelekci N, Goktas O, Koysal Y, Kilic E, Isik S, Aktay G, OzalpM. 1-Acylthiosemicarbazides, 1,2,4triazole-5 $(4 \mathrm{H})$-thiones, 1,3,4-thiadiazoles and hydrazones containing 5methyl-2-benzoxazolinones: synthesis, analgesic-anti-inflammatory and antimicrobial activities.BioorgMed Chem, 2007;15:5738-5751.

Scheurer ML, Pedley TA. The evaluation and treatment of seizures. N Engl J Med, 1990;323:1468-1474.

Siddiqui AA, Arora A, Siddiqui N, Misra A. Synthesis of some 1,2,4-triazoles as potential antifungal agents.Ind J Chem, 2005;44:838841.

Siddiqui N, Pandeya SN, Khan SA, Stables J, Rana A, Alam M, Arshad MF, Bhat MA.Synthesis and anticonvulsant activity of sulfonamide derivatives-hydrophobic domain.Bioorg Med Chem Lett, 2007; 17:255-259.

Smith M, Wilcox KS, White HS.Neurotherapeutics, 2007;4:1217.

Spear BB. Pharmacogenetics and antiepileptic drugs.Epilepsia, 2001;42:31-34

Stables JP, Kupferberg HJ. in: 1997. The NIH anticonvulsant drug developmentprogram: preclinical anticonvulsant screening project. Avanzini G, Tanganelli P, Avoli M. eds.Molecular and cellular targets for antiepileptic drugs, London: John Libbey\& Company Ltd, 16:191-198.
Swinyard EA, Woodhead JH, White HS, Franklin MR, 1989. General principles: experimental selection, quantification, and evaluation of anticonvulsants, in: Levy RH, Mattson RH, Melrum B, Penry JK, Dreifuss FE. $3^{\text {rd }}$ edn. Antiepileptic drugs, New York: Raven-Press 85-102.

Unverferth K, Engel J, Hofgen N, Rostock A, Gunther R, Lankau HJ, Menzer M, Rolfs A, Liebscher J, Muller B, Hofmann HJ. Synthesis, anticonvulsant activity, and structure-activity relationships of sodium channel blocking 3-aminopyrroles. J Med Chem, 1998;41:63-73.

White HS, Woodhead JH, Franklin MR, Mattson RH, Meldrum BS, 1995. Antiepileptic drugs.4th ed, New York: Raven Press 99-110.

Wlaz P, Loscher W. Weak anticonvulsant effects of two novel glycineB receptor antagonists in the amygdala-kindling model in rats.Eur $\mathrm{J}$ Pharmacol, 1998;342:39-46.

\section{How to cite this article:}

Khatoon Y, Shaquiquzzaman M, Singh V, Sarafroz M. Synthesis, Characterization and Anticonvulsant Activity of Some Novel 4, 5Disubstituted-1, 2, 4-Triazole Derivatives. J App Pharm Sci, 2017; 7 (07): 158-167. 